\title{
Financial Inclusion and Turkey
}

\author{
Nuray Terzi \\ Marmara University, Department of Economics, Turkey \\ nurayterzi@marmara.edu.tr
}

Doi:10.5901/ajis.2015.v4n1s2p269

\begin{abstract}
Financial inclusion is the most recent item to be added explicitly to the social inclusion agenda and promotes the need for access among all segments of society to a range of financial services at affordable cost. Small and medium-sized enterprises (SMEs) have played a crucial role in boosting the economy, increasing employment, and creating industries. However, many SMEs in developing economies lack access to loans and lines of credit. With global financial crisis, developing economies have started to promote financial inclusion, especially greater access to financial services for SMEs, as part of their overall strategies for economic and financial development. In this perspective, this study provides a survey of progress on financial inclusion in Turkey on the basis of SMEs.
\end{abstract}

Keywords: Financial Inclusion, Financial Stability, SMEs Financial Inclusion.

\section{Introduction}

In recent years, financial inclusion has been a global agenda. Many countries are employing financial inclusion as an important part of their strategies to achieve inclusive growth. In general, inclusive finance is crucial to sustain economic and social development. It is also expected to lead to greater financial stability and growth.

In terms of three areas, more effort is needed to address gaps in the understanding of financial inclusion. First is the quality of regulatory policies. Ineffective policy measures, too much regulation, or the lack of internal synergies to implement financial inclusion are familiar cautionary tales in all countries. Second, it is also important to have a positive enabling environment for promoting financial inclusion. This means that policies that support financial inclusion have to be closely connected with the pursuit of macroeconomic stability. Financial access is impossible without increasing the capacity of individuals and firms to access higher income levels. Finally, greater financial inclusion is only possible if undertaken responsibly. In as much as inclusion is about increasing the capability to use financial services, it is crucial that those who are directly affected are financially literate and capable (Rillo, 2014).

SMEs have played a crucial role in boosting the economy, increasing employment, and creating industries. However, around 200 million formal and informal micro, small and medium enterprises in developing economies lack access to loans and lines of credit. An estimated about 55 - $68 \%$ of formal SMEs lack adequate financing. SMEs are also held back by inefficient or costly business-to-business payments options; a lack of appropriate risk management products, such as insurance, and a shortage of growth capital. Moreover, women owned SMEs have consistently lower access to finance worldwide (CGAP and IFC, 2013). To increase share of lending to SMEs can help financial stability, mainly by reducing non-performing loans and the probability of default by financial institutions. Moreover, policy measures to increase financial inclusion by SMEs will have the side-benefit of contributing to financial stability.

From this perspective, this study contributes to the literature on this subject by examining the financial inclusion in Turkey on the basis of SMEs. In order to achieve this, the paper is organized as follows. Section 2 gives an overview financial inclusion. Section 3 examines financial inclusion and SMEs. Section 4 analyzes financial inclusion in SMEs in Turkey. Last section provides a conclusion.

\section{An Overview of Financial Inclusion}

Financial inclusion is most commonly thought of in terms of access to credit from a formal financial institution, but the concept has more dimensions. Formal accounts include both loans and deposits, and can be considered from the point of view of their frequency of use, mode of access, and the purposes of the accounts. There may also be alternatives to formal accounts, such as mobile money via mobile telephones. The main other financial service besides banking is 
insurance, especially for health and agriculture (Demirguc-Kunt and Klapper 2012).

Financial inclusion aims at drawing the "unbanked" population into the formal financial system so that they have the opportunity to access financial services ranging from savings, payments, and transfers to credit and insurance (Hannig and Jansen 2010).

The Reserve Bank of India has also defined financial inclusion as the process of ensuring access to appropriate financial products and services needed by all sections of the society in general and vulnerable groups such as weaker sections and low income groups in particular at an affordable cost in a fair and transparent manner by mainstream institutional players (Joshi 2014). Financial inclusion also encompasses the broadening of financial services to those people who do not have access, the deepening of financial services for people who have minimal access (Rajan 2014).

The original Financial Inclusion Action Plan (FIAP) was endorsed by leaders at the Seoul Summit in 2010. Universal financial inclusion requires bringing the 2.5 billion people (or about half the working age population) currently excluded, into the formal financial system. The credit gap for formal and informal micro, small and medium enterprises in emerging and developing economies estimated at US\$2 trillion. Financial inclusion helps build domestic savings, bolster household, domestic and financial sector resilience, and stimulate business and entrepreneurial activity. The cumulative effect of widespread exclusion is increasing inequality, and slower growth and development. The Global Partnership for Financial Inclusion (GPFI) is an inclusive partnership mechanism to take forward the G20's work on financial inclusion. The GPFI produces coordinated analysis and policy recommendations to enhance financial inclusion; facilitates efficient and effective coordination to support various on-going financial inclusion efforts; monitors progress over time and against agreed objectives; and ensures continuity on financial inclusion in global discussions (GPFI, 2014).

In short, financial inclusion addresses: (i) who has access; (ii) how easy it is to access (cost, distance); and (iii) what types of services are accessible. At the Millennium Development Goals Summit of 2010 these elements were combined to define financial inclusion as "universal access, at a reasonable cost, to a range of financial services for everyone needing them, provided by a diversity of sound and sustainable institutions" (Maxima 2010).

Financial inclusion might also affect financial stability both positive and negative. According to Khan (2011) there are three main ways in which greater financial inclusion can contribute positively to financial stability. First, greater diversification of bank assets as a result of increased lending to smaller firms could reduce the overall riskiness of a bank's loan portfolio. This would both reduce the relative size of any single borrower in the overall portfolio and reduce its volatility. This would reduce the "inter-connectedness" risks of the financial system. Second, increasing the number of small savers would increase both the size and stability of the deposit base, reducing banks' dependence on "non-core" financing, which tends to be more volatile during a crisis. This corresponds to a reduction of procyclicality risk. Third, greater financial inclusion could also contribute to a better transmission of monetary policy, also contributing to greater financial stability.

Demirguc-Kunt and Klapper (2012) found that a 10\% increase in the share of people that have access to bank deposits can reduce the deposit growth drops (or deposit withdrawal rates) by 3-8 percentage points, which supports the case that financial inclusion is positive for financial stability. Hannig and Jansen (2010) argue that low-income groups are relatively immune to economic cycles, so that including them in the financial sector will tend to raise the stability of the deposit and loan bases. They suggest that financial institutions catering to the lower end tend to weather macro-crises well and help sustain local economic activity. Prasad (2010) also observes that lack of adequate access to credit for small and medium-size enterprises and small-scale entrepreneurs has adverse effects on overall employment growth since these enterprises tend to be much more labor intensive in their operations.

Khan (2011) also suggested that increased financial inclusion could contribute negatively to financial stability. The most obvious example is if an attempt to expand the pool of borrowers results in a reduction in lending standards. This was a major contributor to the severity of the "sub-prime" crisis in the United States. Second, banks could increase their reputational risk if they outsource various functions such as credit assessment in order to reach smaller borrowers. Finally, if microfinance institutions are not properly regulated, an increase in lending by that group could dilute the overall effectiveness of regulation in the economy and increase financial system risks.

As a result, the literature suggests that greater financial inclusion could be either positive or negative for financial stability. Positive effects include the diversification of bank assets by reducing their riskiness; increased stability of their deposit base, reducing liquidity risks; and improved transmission of monetary policy. Negative effects include the erosion of credit standards bank reputational risk, and inadequate regulation of microfinance institutions. 


\section{Financial Inclusion and SMEs}

A key lesson of the 2007-2009 global financial crisis was the importance of containing systemic financial risk and maintaining financial stability. At the same time, developing economies are seeking to promote financial inclusion, namely greater access to financial services for low-income households and small firms, as part of their overall strategies for economic and financial development (Morgan and Pontines, 2014).

There is a growing body of evidence on the impact of access to financial services at the microeconomic, local economic and macroeconomic levels. Theory presents that an appropriate range of quality financial services helps households smooth consumption, mitigate and manage risks, build assets, and create the peace of mind needed to make effective decisions about the future. Especially, small and medium enterprise owners can use credit or savings to invest in productive assets, insurance to manage risks, and payments services to make transactions more efficient and safe (Table 1).

At the macroeconomic level, the literature shows that financial inclusion is correlated with economic growth and development. An inclusive financial system facilitates inclusive growth by strengthening financial systems, allocating resources more efficiently, and creating opportunities for all (CGAP and IFC, 2013).

Although there has been growing recognition of the importance of SMEs for job creation and economic development, SMEs themselves report lack of access to finance to be one of the greatest barriers to their growth. Half of SMEs in emerging markets are credit constrained. Seventy percent of micro, small, and medium enterprises (MSMEs) have no access to external finance, and another 15 percent are under-financed (IFC, 2013). All this adds up to an estimated credit gap of US\$2 trillion.

Policy reforms vary from country to country such as loan guarantees, government funding, regulations requiring SME finance and infrastructure for SME finance. Studies showed that increased financial inclusion has affected SMES positively. Morgan and Pontines (2014) found some evidence that an increased share of lending to SME aids financial stability, mainly by reducing non-performing loans and the probability of default by financial institutions. This suggests that policy measures to increase financial inclusion, at least by SMEs, would have the side-benefit of contributing to financial stability as well. In addition, reforms in China allowed the rural banking system, once dominated by state-owned banks, to diversify and enabled new market players (such as agro-related banks, village township banks, and postal savings banks) to expand financial services to rural areas. The reforms also resulted in the creation of some innovative products and services for financial inclusion such as the SME Board and ChiNext (Growth Enterprise Board), two innovative funding markets for small and medium-sized enterprises (Rillo, 2014).

\section{SMEs Financial Inclusion and Turkey}

Turkey is the 17th largest economy in the world in terms of GDP, a member of G20, OECD and a candidate for European Union membership. Economic growth in Turkey was briefly interruppted by the 2009 global recession due to the drop in international demand and structural problems with international competitiveness. Turkey recovered quickly but GDP growth slowed in 2014 as a result of weak domestic demand and spill-overs from the European debt crises. Due to domestic political events, Turkey's financial markets and lira have been under pressure and private and public consumption has decreased in real terms.

SMEs in Turkey are most important part of business economy. They provide most jobs, account for $99.9 \%$ of all businesses and produce $53 \%$ of the value added in the whole economy. Especially, micro-SMEs provide almost half (46 $\%$ ) of the employment in Turkey and create about percent of $20 \%$ of total value added (Table 2). For this, the development of SMEs financial inclusion is the center of financial policy in Turkey.

SMEs financial inclusion will be examined by accessing to financial services. Access to financial services is classified into the three sides: the supply side, the demand side and policy perspectives. Supply side includes the distribution of total credits, credits of SMEs and number of banks offering SME credits. Demand side constitutes of usage of external financing by SMEs, significance of factors limiting access to financing and most pressing problems for SMEs. Policy perspective comprises the programs exist to support micro, small and medium-sized enterprises.

\subsection{Supply Side}

Graph 1 shows the distribution of credits in Turkey. According to Graph 1, commercial and corporate credits constitute of the biggest part of the credits. It is $44 \%$ of total credits. Consumer credits and credit cards are $29 \%$ of total credit. The 
share of SMEs credits is $27 \%$ of total credits.

The SMEs credits have increased since 2009. Micro, small and medium sized SMEs credits increased more than three times between 2009 and 2014. However, there is a slower in increase in SMEs credits in recent years (Graph 2). An OECD report (2012) identified gaps in microfinance. However, domestic bank lending to the private sector has increased significantly in recent years: around $80 \%$ of loans to SMEs come from commercial banks. The government encourages public and private banks to increase lending to SMEs, so banks are very inclined to offer loans. Only outside the major cities does access to finance remain a challenge (EC, 2014).

In Turkey, 21 banks provide SME loans. Most of them is privately-owned deposit banks and foreign banks founded in Turkey. A few is state-owned and privately owned development and investment bank. Others are state-owned deposit banks and privately-owned participation banks (Table 3). In addition, 74 specialized leasing companies offer leasing, and 76 specialized factoring companies provide factoring services. 2 MFIs provide microcredit to low income female entrepreneurs. 2 public loan funds provide loan-interest loans to SMEs. SMEs have access to a variety of financing products: loans (such as cash loans, discount and purchase loans, spot loans, day loans), overdrafts, credit cards, noncash loans (letter of credit, letter of guarantee), factoring and leasing services (Microfinance Center, 2014).

\subsection{Demand Side}

$71 \%$ of SMEs have used debt financing within the last 6 months. Bank loans are the most common source of external financing, used by $58 \%$ of SMEs. Trade credit is the second most popular instrument, used by $47 \%$ of SMEs. Overdraft facilities, and leasing/factoring facilities, are less frequently used in Turkey (Graph 3).

According to EU SAFE research (2013), over 40\% of SMEs in Turkey do not see any obstacles to obtain financing. Low affordability, and high interest rates, on credit are perceived the biggest concern in using external funding affecting more SMEs in 2013 compared to 2 years previously. High guarantee requirements are the second most limiting factor in accessing SME credit, although experienced by fewer SMEs in 2013 than in 2011. SME credit is usually indexed to foreign currencies so currency fluctuations affect credit cost. Long-term loans (over 10 years) are rarely available, limiting larger investments in company development (Graph 4).

Additionally, access to finance is not the biggest problem facing Turkish SMEs. 16\% of them consider lack or limited access to be the biggest constraint, making it fourth in the list of pressing concerns. The most pressing problems for Turkish SMEs are difficulties in finding customers, skilled staff and experienced managers, as well as high costs of the production and labour (Graph 5).

\subsection{Policy perspectives}

In Turkey, a number of programs exist to support micro, small and medium-sized enterprises. There are four separate government investment operations that provide funding for SMEs: Angel Investment Scheme, G 43 Anatolian Venture Capital Fund, KOBI Venture Capital Investment Trust, and Istanbul Venture Capital Initiative.

The first, the "Angel Investment Scheme," program is designed to provide financing and technical assistance for small, start-up SMEs that lack adequate collateral and also need help with the essentials of good business practices. The Turkish Treasury offers tax incentives for angel investors (75 percent of the amount invested can be deducted from taxes, and up to 100 percent in the case of SMEs that are involved in government-supported technical projects). Angel investors can own up to 50 percent of the shares in the SME, with the shares held for at least two years, and are also expected to provide technical assistance to their SMEs. The minimum amount to be invested is just under US $\$ 10,000$, while the maximum is just over US\$475,000. According to Ertürk and Öcal (2014) during the first year of the program, 182 business angels have been licensed and several networks of angel investors are also being added to the program. This rapid start-up can be attributed to efforts to mobilize supporters, in both the public and private sectors, with the enabling legislation also being prepared with similar support. During just the first year of the program, there have been five angel investments for slightly under US\$850,000 and for an average of about US\$170,000, with others currently being assessed for support.

The second program is a venture capital fund for the 43 provinces of Anatolia, funded primarily by EU's Instrument for Pre-Accession Assistance (IPA), with the collaboration of two Turkish government agencies, the Ministry of Science, Industry, and Technology as the operating structure, and the Small and Medium Enterprises Development Organization (KOSGEB) as the recipient of assistance. The European Investment Fund (EIF) is the trustee administrator for the EIFIPA Commitment. An initial agreement was signed in August 2011, with a further agreement in December, and operations 
starting at the end of 2013. The fund manager and the Istanbul Venture Capital Initiative are also investors in the fund. Although research for investments in SMEs has started, no funds have as yet been disbursed (KOSGEB, 2014). G-43 Anatolian Venture Capital Fund targets SMEs especially in developing regions of Turkey.

The third program, the KOBI Venture Capital Investment Trust, began operations in 2006 with three main partners, including both the public and private sectors (KOSGEB, TOBB, and Halkbank), with the purpose of investing in local SMEs that show high potential for innovation. In providing both financial and managerial support to qualifying SMEs, KOBI's investments are limited to 49 percent of the SME's capital and can range from US $\$ 250,000$ up to US $\$ 1$ million, depending mainly on the wide range of business types supported. Potential investments are based on a detailed list of specific criteria and also include a position on the SME's managerial board. Therefore, after the investment is made, $\mathrm{KOBI}$ remains highly involved: preparing and implementing business plans, carefully measuring both targets and accomplishments and, at times, even in day-to-day operations. Given these high criteria, investing in only 10 of 2,124 applicants, it is not surprising that these 10 businesses are all highly successful, with sales and profits increasing every year in virtually every case, and their excellent growth often requiring substantial additional investments (Öktem, 2014).

The fourth Turkish program, the Istanbul Venture Capital Initiative (iVCi), established in 2007, is also partly funded by the EU through its European Investment Fund, along with the National Bank of Greece Group, Garanti Bank, and various Turkish government entities, including KOSGEB, the Technology Development Foundation of Turkey and the Development Bank of Turkey. The iVCi invests for a long time horizon, six to 10 years, and in private equity and venture capital funds, as well as directly, along with other funds, in SMEs. As of the end of March 2014, it had invested over US $\$ 95$ million, with commitments of over US\$195 million. As a "fund of funds," iVCi believes that its main contribution has been to stimulate the development of various other funds by demonstrating what can be done directly, as well as by investing in other funds. Fourteen SMEs had benefited directly from iVCi investments as of the end of March 2014, with 25 percent of its investments ultimately going to SMEs (KOSGEB, 2014).

\section{Conclusion}

Financial inclusive growth has recently become one of the world's most important policy goals, and economists have given attention to SMEs financial inclusion. SMEs play a crucial role in boosting the economy, increasing employment, and creating industries. Therefore, this study analyzed financial inclusion in Turkey on the basis of SMEs in terms of supply side, demand side and policy perspectives.

On the supply side, SMEs credits have increased since 2009. As a result of this, there is a broad SME credit usage with many firms taking bank loans. Enterprise credit available from the majority of deposit banks both state-owned and foreign bank. On the demand side, bank loans are the most common source of external financing and trade credit is the second most popular instrument. Others, such as overdraft facilities, and leasing/factoring facilities, are less frequently used in Turkey. Low affordability, and high interest rates, on credit are perceived the biggest concern in using external funding affecting more SMEs. High guarantee requirements are the second most limiting factor in accessing SME credit. Additionally, access to finance is not the biggest problem facing Turkish SMEs. The most pressing problems for Turkish SMEs are difficulties in finding customers, skilled staff and experienced managers, as well as high costs of the production and labor. In terms of policy perspectives, government focuses on improving financial inclusion of SMEs with Angel Investment Scheme, G- 43 Anatolian Venture Capital Fund, KOBI Venture Capital Investment Trust, and Istanbul Venture Capital Initiative programs. These programs have started to give their positive results. In summary, SMEs will be continuing the most important part of business economy in Turkey. They provide most jobs, account for most of all businesses and produce more than half of the value added in the whole economy. Therefore, policy measures to increase SMEs financial inclusion will contribute to financial stability as well as economic growth in Turkey.

\section{References}

BRSA (2014). Turk Banking Sector Main Indicators, September.

CGAP and IFC (2013). Financial Inclusion Targets and Goals: Landscape and GPFI View, October,http: //www. gpfi. org/sites/default/files/documents/Financial\%20Inclusion\%20Targets\%20and\%20Goals. pdf.

Demirguc-Kunt, A. ,and L. Klapper. (2012). Measuring Financial Inclusion: The Global Findex Database. Development Research Group Policy Research Working Paper No. 6025. Washington, DC : World Bank.

EC (2014). 2014 SBA Fact Sheet: Turkey, European Commission.

Ertürk H. and Öcal, K, (2014). "Turkey: Angel Investment Sheme" Enhancing SME Access to Finance-Case Studies, IFC.

GPFI (2014). 2014 Financial Inclusion Action Plan. GFPI. 
Hannig, A. , and S. Jansen. (2010). Financial Inclusion and Financial Stability: Current Policy Issues. ADBI Working Paper 259. Tokyo: Asian Development Bank Institute. Available: http: //www. adbi. org/workingpaper/2010/12/21/4272. financial. inclusion. stability. policy. issue.

IFC/McKinsey \& Company (2013). Two Trillion and Counting: Assessing the Credit Gap for Formal and Informal SMEs.

Joshi, D. P. (2014). Strategy Adopted for Financial Inclusion. Address at a workshop organized by the Government of Madhya Pradesh. New Delhi. 24 January.

Khan, H. R. (2011). Financial Inclusion and Financial Stability: Are They Two Sides of the Same Coin? Address by Shri H. R. Khan, Deputy Governor of the Reserve Bank of India, at BANCON 2011, organized by the Indian Bankers Association and Indian Overseas Bank, Chennai, India, 4 November.

KOSGEB (2014). Turkey : G43 Anatolian Venture Capital Fund, Enhancing SME Access to Finance-Case Studies, IFC.

KOSGEB (2014) Turkey: Istanbul Venture Capital Initiative, Enhancing SME Access to Finance-Case Studies, IFC.

Maxima, P. (2010). Financial Inclusion: A Path to the Millennium Goals. Speech by the UN Secretary-General's Special Advocate for Inclusive Financed for Development at a side event during the MDG Summit 2010. http: //www. koninklijkhuis. nl/ globalepaginas/taalrubrieken/english/speeches/speeches-archive/2010/september/speech-by-princess maxima-un-secretarygeneral\%E2\%80\%99sspecial-advocate-for-inclusive-finance-for development/

Morgan, Peter J. and Victor Pontines (2014). Financial Stability and Financial Inclusion, Asian Development Bank Institute Working Paper Series, No. 488, p. 1-16.

OECD (2012). SME Policy Index: Western Balkans and Turkey 2012: Progress in the Implementation of the Small Business Act for Europe, OECD Publishing, p 249-250. http: //dx. doi. org/10. 1787/9789264178861-en

Öktem, O. (2014). Turkey: Venture Capital Investments, Enhancing SME Access to Finance-Case Studies, IFC.

Prasad, E. (2010). Financial Sector Regulation and Reforms in Emerging Markets: An Overview. NBER Working Paper 16428. Cambridge, MA: National Bureau of Economic Research.

Rajan, R. (2014). Financial Inclusion-Technology, Institutions, and Policies. Keynote Address at the National Association of Software and Services Companies India Leadership Forum. Mumbai. 12 February.

Rillo, D. Aladdin (2014). An Overview of Financial Inclusion in Asia, Financial Inclusion in Asia: Country Survey, Asian Development Bank Institute.

Table 1. The Use of Financial Services

\begin{tabular}{|c|l|l|}
\hline & Individuals/Micro Enterprises & Small and Medium Enterprises \\
\hline Credit & $\begin{array}{l}\text { *Consumption smoothing } \\
\star\end{array}$ Investment in human development (health, education,etc. ) & $\begin{array}{l}\text { *Financing for working capital and for investment } \\
\text { *From financial institutions or through supply chain }\end{array}$ \\
\hline Savings & $\begin{array}{l}\text { *Cushion in case of shocks } \\
\text { * Low-risk source of self-financing }\end{array}$ & $\begin{array}{l}\text { *Savings (retained earnings) as primary source of } \\
\text { financing }\end{array}$ \\
\hline Insurance & Risk-management tool for managing shocks & *Lower risks of business activity \\
\hline Payments & $\begin{array}{l}\text { Safe and low-cost alternatives to informal mechanisms and } \\
\text { cash }\end{array}$ & *For efficient, low cost, and safe transactions \\
\hline
\end{tabular}

Source: CGAP and IFC (2013), Financial Inclusion Targets and Goals: Landscape and GPFI View,October,http: //www. gpfi. org/sites/default/files/documents/Financial\%20Inclusion\%20Targets\%20and\%20Goal.pdf

Table 2. SMEs in Turkey

\begin{tabular}{|c|c|c|c|c|c|c|}
\hline & \multicolumn{2}{|c|}{ Number of enterprises } & \multicolumn{2}{c|}{ Number of employees } & \multicolumn{2}{c|}{ Value added } \\
\hline & Number & Proportion & Number & Proportion & Billion $€$ & Proportion \\
\hline Micro & 2.326 .148 & $97.3 \%$ & 5.019 .845 & $46.5 \%$ & 29 & $19.6 \%$ \\
\hline Small & 42.641 & $1.8 \%$ & 1.327077 & $12.3 \%$ & 19 & $12.7 \%$ \\
\hline Medium Sized & 18.132 & $0.8 \%$ & 1.830 .242 & $16.9 \%$ & 30 & $20.6 \%$ \\
\hline SMEs & 2.386 .921 & $99.9 \%$ & 8.177 .164 & $75.7 \%$ & 78 & $52.9 \%$ \\
\hline Large & 3.506 & $0.1 \%$ & 2.626 .790 & $24.3 \%$ & 69 & $47.1 \%$ \\
\hline Total & 2.390 .427 & $100.0 \%$ & 10.803 .954 & $100.0 \%$ & 147 & $100.0 \%$ \\
\hline
\end{tabular}

Source: Turkish Statistical Institute.

Table 3. Number of Banks Offering SME Credit, March 2014

\begin{tabular}{|c|c|}
\hline Privately -owned deposit banks & 8 \\
\hline Foreign banks founded in Turkey & 6 \\
\hline State-owned deposit banks & 3 \\
\hline Privately owned development and investment banks & 3 \\
\hline Privately owned participation banks & 2 \\
\hline State-owned development and investment bank & 1 \\
\hline
\end{tabular}

Source: Microfinance Center. 
Graph. 1. Distribution of Credits in Turkey, September 2014.

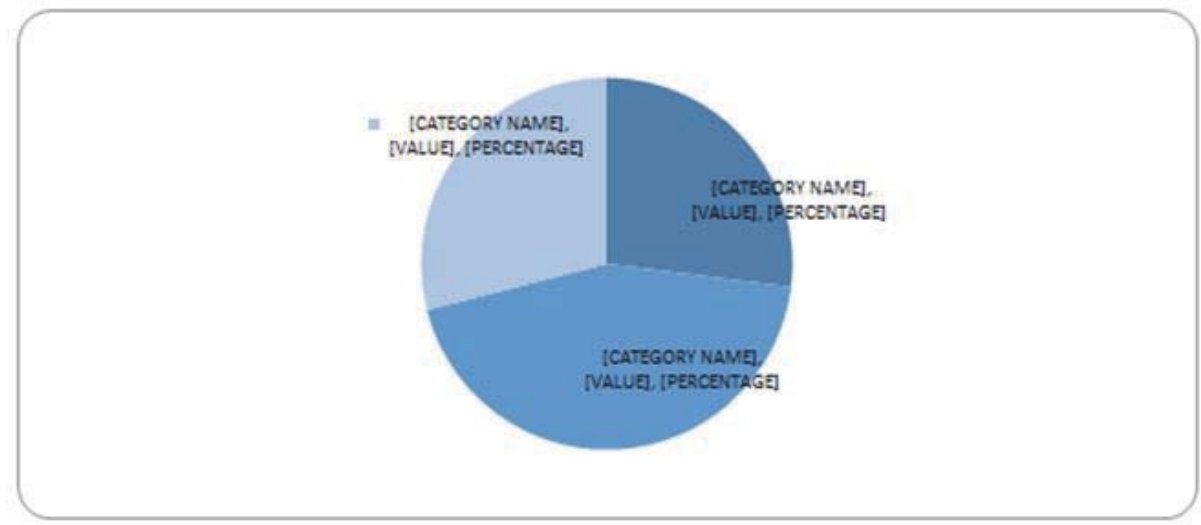

Source: BRSA, 2014.

Graph 2. Credits of SMEs in Turkey, Billion TL.

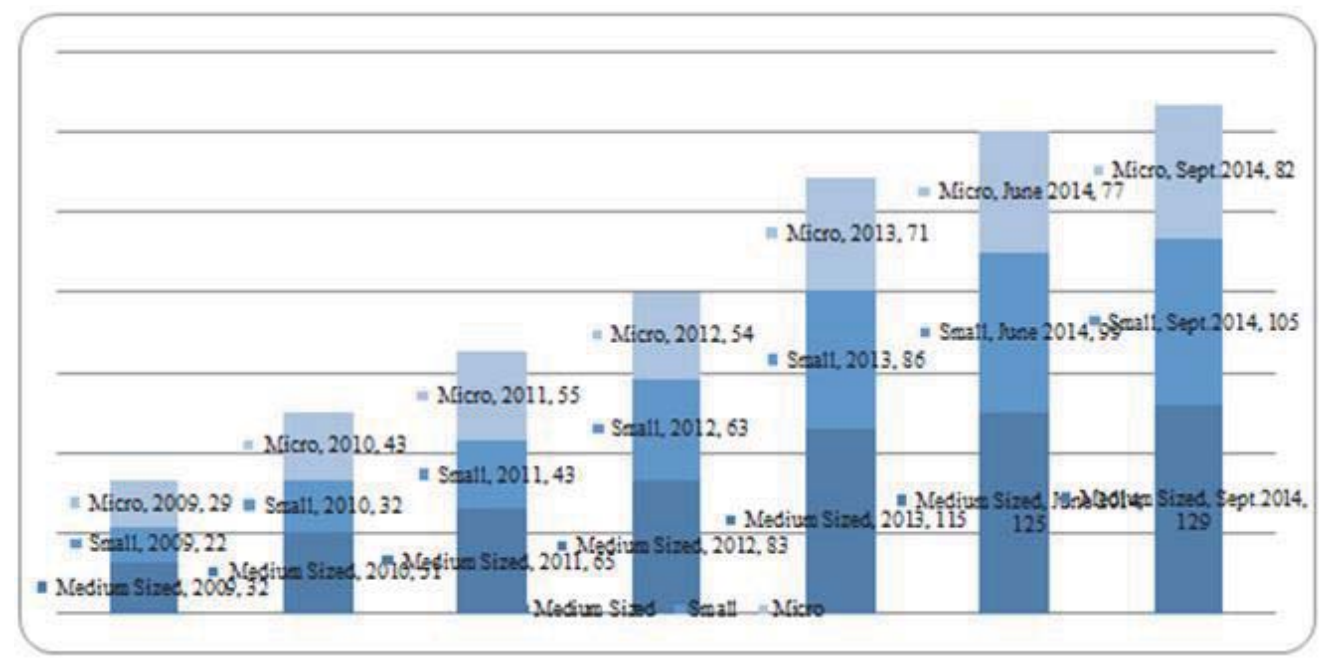

Source: BRSA, Turk Banking Sector Main Indicators, September, 2014.

Graph 3. Usage of External Financing by SMEs (\% firms)

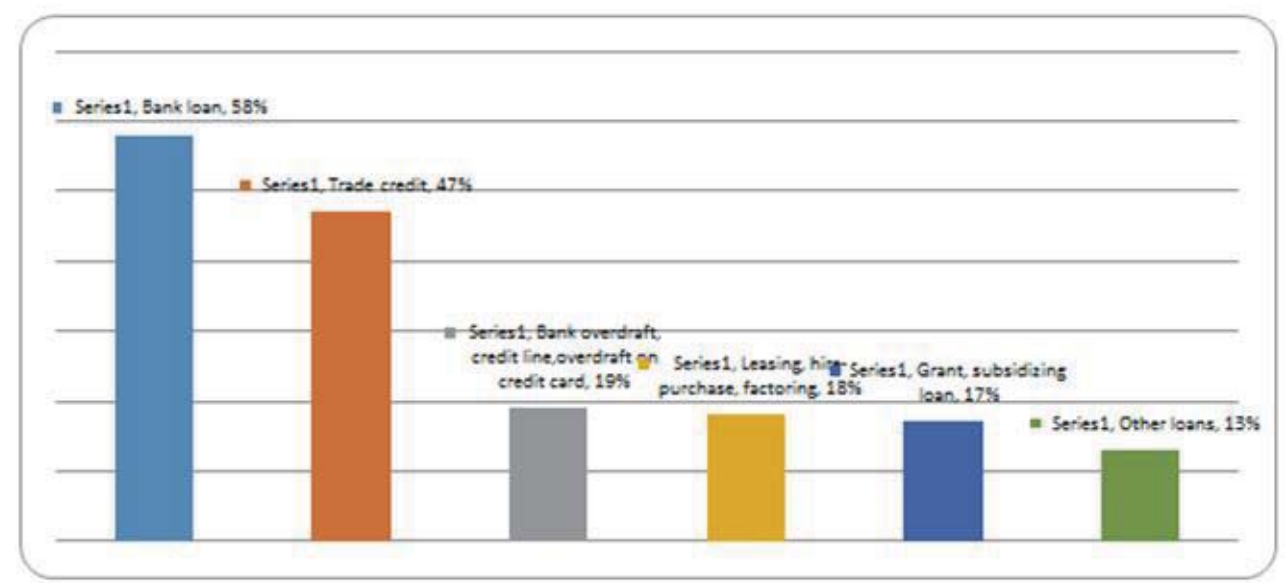

Source: EU SAFE 2013. 
Graph 4. Significance of Factors Limiting Access to Financing

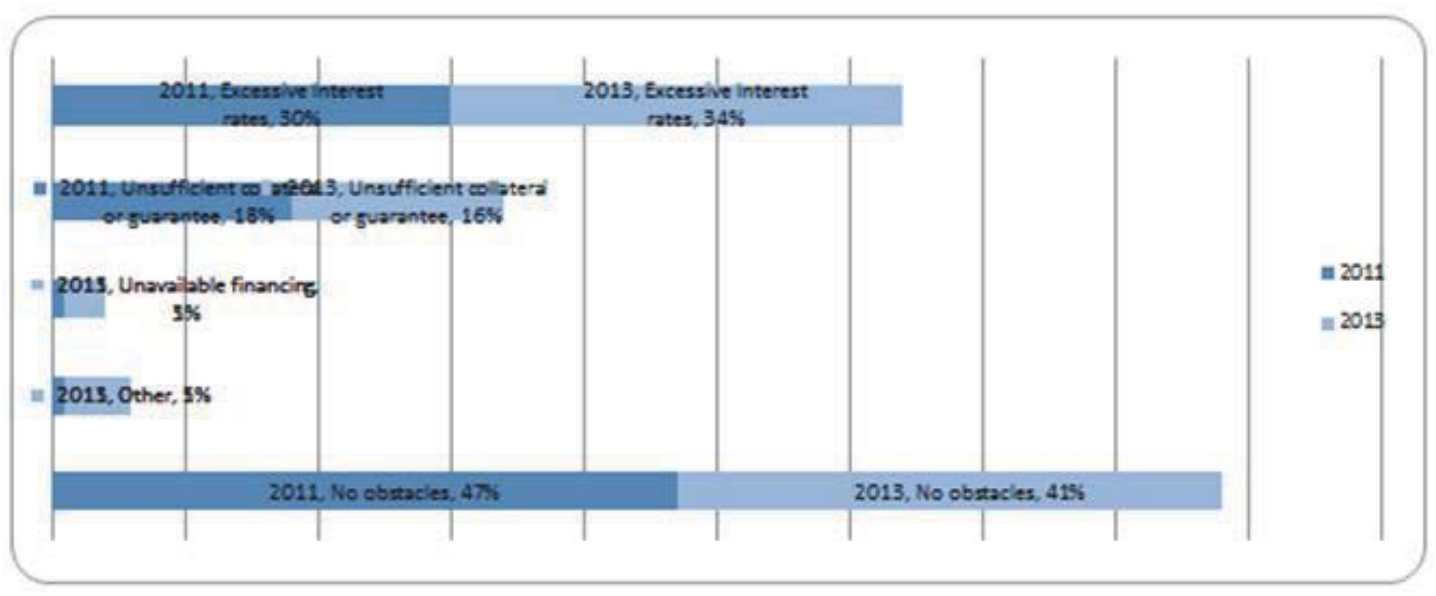

Source: EU SAFE 2013.

Graph 5. Most pressing problems for SMEs

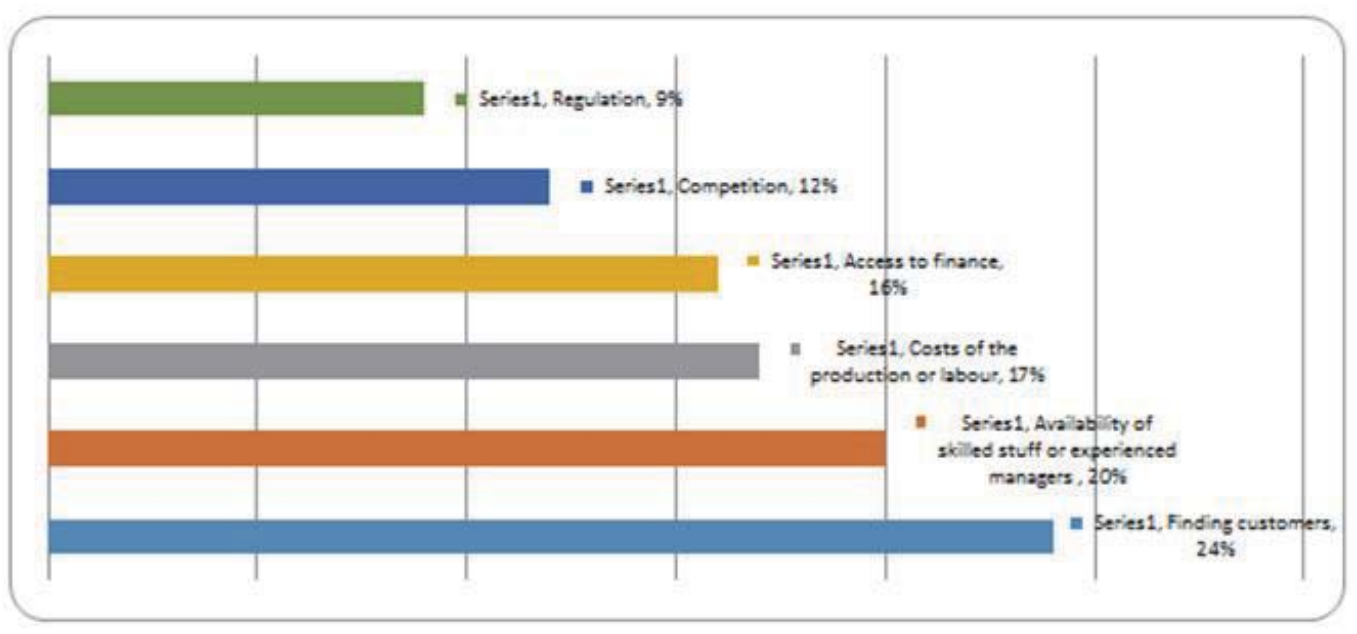

Source: EU SAFE 2013. 